\title{
Effects of abusive temperatures on the postharvest quality of lettuce leaves: ascorbic acid loss and microbial growth
}

\author{
María del R. Moreira ${ }^{a b}$, Alejandra G. Ponce ${ }^{b}$, Carlos E. del Valle $^{a}$, R. Ansorena ${ }^{b}$ \\ and S.I. Rourab
}

${ }^{a}$ Universidad Nacional de Mar del Plata, Argentina; ${ }^{b}$ Consejo Nacional de Investigaciones Cientificas y Técnicas (CONICET), Argentina. *Corresponding author: Moreira María del Rosario, Grupo de Investigación en Ingeniería en Alimentos, Facultad de Ingeniería, Universidad Nacional de Mar del Plata (UNMDP)- Argentina. Juan B. Justo 4302, CP: 7600. Mar del Plata. Provincia de Buenos Aires.Argentina._E-mail: moreira_maria@fi.mdp.edu.ar.

\begin{abstract}
Changes in lettuce leaf quality (ascorbic acid contents and microbial populations) at two abusive temperatures $\left(8\right.$ and $\left.15^{\circ} \mathrm{C}\right)$, simulating the commercial storage conditions for fresh vegetables were analyzed. A storage temperature of $8^{\circ} \mathrm{C}$ was chosen to simulate abusive refrigerated storage and a storage temperature of $15^{\circ} \mathrm{C}$ was chosen to simulate room temperature. Quality indicators evaluation in samples, stored at abusive temperatures were compared with sample from optimal storage temperature $\left(0^{\circ} \mathrm{C}\right)$. First order kinetics is assumed for ascorbic acid degradation. Ascorbic acid degradation rate in lettuce leaves stored at abusive temperatures was from 2.7 to 2.9 times faster than at $0^{\circ} \mathrm{C}$. The growth curve of total microbial counts was fitted with the Gompertz and Logistic models. These models allowed us to predict the vegetable microbiological shelf life. Temperature is the controlling factor for lettuce shelf life and quality; microbial quality was retained 1.6 and 4 times longer at $0^{\circ} \mathrm{C}$ with respect to 8 and $15^{\circ} \mathrm{C}$, respectively.
\end{abstract}

Key words: Abusive temperature storage, nutritional quality, microbiological quality, shelf life, growth models, lettuce, Lactuca sativa, ascorbic acid retention

\section{Introduction}

Vegetables are important components in a balanced human diet. They are low in fat, low in calorie with high carbohydrate and fiber contents. They provide significant levels of some micronutrients. Fresh vegetables have a short shelf life when they are exposed to conditions that destroy their quality attributes. Fresh vegetable quality is affected by various factors, including post-harvest handling and storage conditions (temperature, relative humidity, light and atmosphere composition). Minimum safe low temperatures and high relative humidity control are the most important tools for extending the shelf life of most fresh vegetables. Temperature is the single most important variable and its improper manipulation causes evident changes in the sensory characteristics of fresh vegetables that condition consumers acceptability. Abusive storage temperatures also lead to reduce levels of some nutrients, mainly ascorbic acid, and favor microorganisms proliferation to levels that may exceed tolerable levels (Francis et al., 1999). Fresh fruits and vegetables probably receive the greatest temperature abuse at the retail level. Temperature abuse is a function of time and temperature during holding and the relative perishability of a particular commodity (Paull, 1999).

Fresh vegetables are a major source of ascorbic acid, a nutrient that besides its vitamin action, is valuable for its antioxidant effects, its stimulation of the immune system and other health benefits that are being actively investigated and reported (Giannakourou and Taoukis, 2003). While the assessment of ascorbic acid content does not represent a complete nutritional evaluation, this compound is very labile and therefore it gives a sensitive index of relative nutritional quality (Perrin and Gaye, 1986).

Another basic phenomenon that confronts the extension of fresh vegetables shelf life is the microorganisms proliferation. Disease-causing microorganisms' growth is a food safety concern, especially with high $\mathrm{pH}$ vegetables. Visible growth and off-odors caused by microorganisms are also objectionable. Various treatments and strategies have been evaluated to aid in the management of post-processing microbial populations, e.g. use of sanitizing solutions (chlorine water, hydrogen peroxide, sodium dichloroisocyanurate, etc.), modified atmosphere control and irradiation with a gamma source (Zagory, 1999). However, most of the research evaluating the efficiency of sanitizer for eliminating microorganisms to date has not been promising (Brackett, 1999).

The first few hours after harvest can be crucial for the fresh vegetables shelf life. Although temperatures close to $0{ }^{\circ} \mathrm{C}$ are recommended, fresh vegetables may be prepared, shipped and stored at $5{ }^{\circ} \mathrm{C}$ and, sometimes as high as $10^{\circ} \mathrm{C}$ (Watada et al., 1996). Handling at this elevated level can hasten deterioration because $\mathrm{Q}_{10}$ of biological reactions range from 3 to 4 and possibly as high as 7 within this temperature region (Wiley, 1997). The paramount marketing tool for fresh vegetables is strict avoidance of temperature abuse during processing, distribution, and merchandising to achieve the required or near maximum shelf life for each product (Schlimme, 1995). Although research are needed to determine the kinetic parameters that help to model the changes in quality attributes of fresh products (Giannakourou and Taoukis, 2003), these studies were done in similar conditions found in commercial practices. The significance of laboratory studies and 
to a lesser extent simulated shipping studies may not be relevant to commercial practices in many cases (Paull, 1999).

The purpose of the present work was to analyze changes in lettuce leaf quality kept at two abusive temperatures ( 8 and 15 ${ }^{\circ} \mathrm{C}$ ) simulating the commercial sales practice of fresh vegetables. A storage temperature of $8^{\circ} \mathrm{C}$ was chosen to simulate abusive refrigerated storage and a storage temperature of $15^{\circ} \mathrm{C}$ was chosen to simulate room temperature. Quality indicators evaluation in sample stored at abusive temperatures was compared to the optimal storage temperature $\left(0^{\circ} \mathrm{C}\right)$. Quality changes of lettuce leaves were analyzed through nutritional indicators (ascorbic acid retention), microbiological (total microbial counts) and other physicochemical parameters such as soluble solids contents, water loss and weight loss. In the present work, only tap water immersion was used to eliminate superficial microflora; in this way, only temperature effects on microbial evolution was evaluated. In addition, Gompertz and Logistic models were applied to predict the vegetable microbiological shelf life.

\section{Materials and methods}

Sample preparation: Heads of Romaine lettuce (Lactuca sativa, type Cos, variety Logifolia) were harvested at optimal maturity when they reached a marketable size (approximately 20-24 leaves per head). They were immediately transported to the laboratory. To reduce natural variability among samples, lettuce leaves were sorted for integrity, color and size uniformity, and lack of defects. Outer leaves were discarded and only photosynthetic leaves (green leaves) were included in the samples. Lettuce leaves were dipped in tap water for $4 \mathrm{~min}$ at room temperature $\left(20{ }^{\circ} \mathrm{C}\right)$ in a ratio of one part of lettuce for 10 parts of water. Lettuce leaves were then centrifuged for $30 \mathrm{sec}$ at $200 \mathrm{rpm}$ in a salad spinner to remove excess water. Leaves were piled up in $120 \mathrm{~g}$ stacks and placed in polyethylene bags $(25 \times 20 \mathrm{~cm}$, useful volume: 1.81 ) with an $\mathrm{O}_{2}$ permeability of $520-4000 \mathrm{~cm}^{3} \mathrm{~m}^{-2}$ day $^{-1}$, $\mathrm{CO}_{2}$ permeability of $3900-10000 \mathrm{~cm}^{3} \mathrm{~m}^{-2}$ day $^{-1}$ and water vapor of 4-10 $\mathrm{g} \mathrm{m}^{-2} \mathrm{day}^{-1}$. Samples were placed in boxes with overall dimensions of $0.4 \times 0.3 \times 0.3 \mathrm{~m}$, made of heavy-duty, $0.60 \mathrm{~cm}$ thick, transparent acrylic, with $97-99 \%$ relative humidity, and stored at 0,8 and $15^{\circ} \mathrm{C}$ for approximately $200 \mathrm{~h}$. In samples stored at $15^{\circ} \mathrm{C}$ ascorbic acid and microbiological determinations were stopped earlier because, from a sensorial point of view, they were deteriorated beyond any commercial value.

Physicochemical determinations: Samples were weighed to determine weight loss during storage. Moisture was determined by the weight loss of $10 \mathrm{~g}$ samples after $24 \mathrm{~h}$ at $80^{\circ} \mathrm{C}$ (Bastrash et al., 1993). $30 \mathrm{~g}$ of lettuce leaf juice was obtained with a home juice maker and centrifuged at $2000 \mathrm{rpm}$ for $5 \mathrm{~min}$. Juice samples were diluted (1:1) with distilled water. Soluble solids were determined on the diluted samples with an Abbe refractometer (Kim et al., 1993). At each sampling period, two samples from each experimental condition were taken for the analysis. Analyses were performed on each sample in duplicate.

Determination of ascorbic acid: Ascorbic acid contents were determined according to Moreira et al. (2003). Lettuce leaves were ground with a tissue homogenizer (Multiquick, MR 5550 $\mathrm{CA}$, Braun) for $1 \mathrm{~min}$. Twenty grams of lettuce was homogenized with $40 \mathrm{~mL}$ of oxalic acid solution $0.5 \mathrm{~g} / 100(\mathrm{w} / \mathrm{w})$. The mixture was filtered through Whatman \# 42 filter paper. Aliquots (10 $\mathrm{mL}$ ) of the filtrate were titrated with 2,6-dichloroindephenol. To prepare solutions, copper-free water was used. Since copper may be present in the lettuce samples, titration was performed rapidly to minimize interfering effects. Ascorbic acid contents are reported as mg / 100g sample on a wet basis. Ascorbic acid determination was performed on three different experimental runs at each storage temperature. For each experimental run two samples were taken and analysis was performed in triplicate.

Microbial population: Ground lettuce (10 g) was macerated in a buffer solution $\left(\mathrm{PO}_{4} \mathrm{~K}_{3}, \mathrm{pH}=7.2\right)$. Total microbial counts were done on plate count agar (PCA) after incubation for 48 $\mathrm{h}$ at $35^{\circ} \mathrm{C}$ (ICMSF, 1983, Mossel and Moreno García, 1985). Microbial counts in fresh lettuce leaves were performed on three independent experimental runs for each storage condition analyzed. At each sampling time, two sample lots were analyzed by duplicate.

Primary growth models application: Experimental values were fitted with the Gompertz model (Zwietering et al., 1990) and the Logistic model (Ricker, 1979). The Gompertz model is:

$\log \mathrm{N}=A+C \cdot e^{\left(-e^{(-B \cdot(t-M)}\right)}$

Where, $\log \mathrm{N}$ is the decimal logarithm of microorganisms counts at time $\mathrm{t}$; $\mathrm{A}$ is the asymptotic value when time decreases indefinitely (approximately equivalent to the decimal logarithm of the initial microorganisms counts); $\mathrm{C}$ represents the increase in the logarithm of microorganisms counts when time increases indefinitely (number of $\log$ cycles); $\mathrm{B}$ is the maximum rate of growth related to time $\mathrm{M}$ and $\mathrm{M}$ is the time required to reach the maximum rate of growth. The logistic model is: (Ricker, 1979) $\log \mathrm{N}=A+\frac{C}{1+e^{\left(D-F^{*} t\right)}}$

Where, $\log \mathrm{N}, \mathrm{A}$ and $\mathrm{C}$ has the same meaning as in the Gompertz model. $\mathrm{D}$ is a dimensionless parameter and $\mathrm{F}$ is the rate of growth relative to the mean time of the exponential phase.

Statistical analysis: Linear correlations significance was tested according to Volk (1980). Differences among slopes for the evolution of ascorbic acid at different storage temperatures were tested as indicated by Volk (1980). Whenever differences are reported to be significant, a 95\% confidence level was used.

Estimation of the parameters in both Gompertz and the Logistic models was done with the function lsqcurvefit from Mathlab 7.0 .

\section{Results and discussion}

Physicochemical parameters: Lettuce leaves weight losses during storage are presented in Fig. 1. The weight loss increased with the storage temperatures and, after $170 \mathrm{~h}$ of storage, they amounted to $0.6,1.0$ and $1.6 \mathrm{~g} / 100 \mathrm{~g}(\mathrm{w} / \mathrm{w})$ in samples held at 0 , 8 and $15^{\circ} \mathrm{C}$, respectively. Weight loss of fresh vegetables can be attributed to: (1) evaporation of surface water remaining on the product after washing; (2) dehydration, that is water loss due to the difference in water vapor pressure between the surrounding atmosphere and the foodstuff; and (3) respiration, which consist in the breakdown of carbohydrates to produce carbon dioxide and water. Since the samples were kept in polyethylene bags with very low permeability to water vapor and with relative humidity 


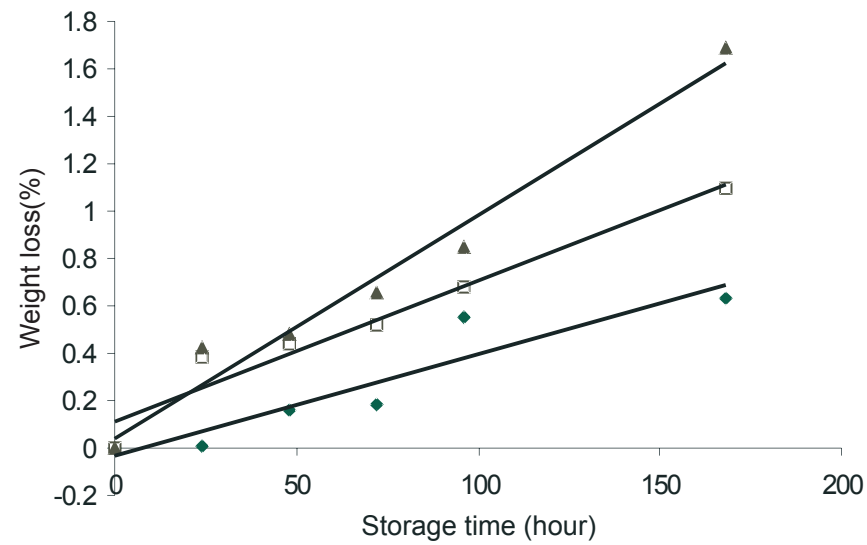

Fig. 1. Lettuce leaf weight loss, as percentage of fresh weight, during storage at $0^{\circ} \mathrm{C}(\diamond)(\mathrm{y}=0.0043 \mathrm{x}-0.0343, \mathrm{R}=0.94), 8^{\circ} \mathrm{C}(\square)(\mathrm{y}=0.0059 \mathrm{x}$ $+0.1156, \mathrm{R}=0.97)$ and $15^{\circ} \mathrm{C}(\mathbf{\Delta})(\mathrm{y}=0.0094 \mathrm{x}+0.0432, \mathrm{R}=0.98)$.

above $98 \%$, weight loss would be due to respiration.

Initial water contents in lettuce leaves were $94.56 \pm 0.53 \mathrm{~g} / 100$ $\mathrm{g}(\mathrm{w} / \mathrm{w})$. After $170 \mathrm{~h}$ of storage the water contents of samples stored at $0^{\circ} \mathrm{C}$ were $94.84 \pm 0.21 \mathrm{~g} / 100 \mathrm{~g}(\mathrm{w} / \mathrm{w})$. In samples stored at $8^{\circ} \mathrm{C}$ they were $95.14 \pm 0.29 \mathrm{~g} / 100 \mathrm{~g}$ and in samples stored at $15^{\circ} \mathrm{C}$ they were $95.83 \pm 0.6 \mathrm{~g} / 100 \mathrm{~g}(\mathrm{w} / \mathrm{w})$. These increases in water contents would correspond to water produced by respiration. While carbon dioxide is lost to the atmosphere, water is retained by the food and weight loss is independent of moisture loss (Sastry and Buffington, 1982). Polyethylene bags provide high relative humidity, so dehydratation typically is not a problem. However, moisture may condense on the inner surface of the bag, detracting visual appearance and providing conditions for microbial growth.

Initial soluble solid contents in lettuce leaves were $3.9 \pm$ $0.24^{\circ}$ Brix. After $170 \mathrm{~h}$ of storage, the soluble solids contents of samples held at 0 and $8^{\circ} \mathrm{C}$ were not significantly different from the initial value $(P<0.01)$. However, in samples stored at $15^{\circ} \mathrm{C}$ the final soluble solids contents were significantly lower $(P<0.01)$ with a value of $3.06 \pm 0.32^{\circ} \mathrm{Brix}$. This decrease in soluble solids could be attributed to sugar consumption through respiration.

Ascorbic acid contents: The initial ascorbic acid contents of lettuce leaves ranged between 6.0 and $16.6 \mathrm{mg} / 100 \mathrm{~g}$ of sample with a mean value of $10.9 \pm 2.9 \mathrm{mg} / 100 \mathrm{~g}(\mathrm{n}=40)$. Moreira et al. (2005) and Roura et al. (2003) reported similar initial mean values for ascorbic acid contents in lettuce leaves $(8.3 \pm 1.0$ and $9.4 \pm 1.6 \mathrm{mg} / 100 \mathrm{~g}$ of sample, respectively). The wide range of values for the initial ascorbic acid contents in lettuce leaves would reflect the influence of various factors such as climate conditions, cultural practices, maturity at harvest, harvesting method and post-harvest handling conditions (Lee and Kader, 2000). Of course, the inherent variability in biological systems would also contribute to this variability.

First order kinetics is assumed for ascorbic acid degradation. Therefore, the natural logarithm of ascorbic acid contents ratio to the initial ascorbic acid contents against time should fall on a straight line with the slope representing the apparent reaction constant. Ascorbic acid contents in lettuce leaves kept at the different storage temperature are presented in this way in Fig. 2. The slopes of the straight tendency lines for samples stored at 8 and $15^{\circ} \mathrm{C}$ were not significantly different between themselves

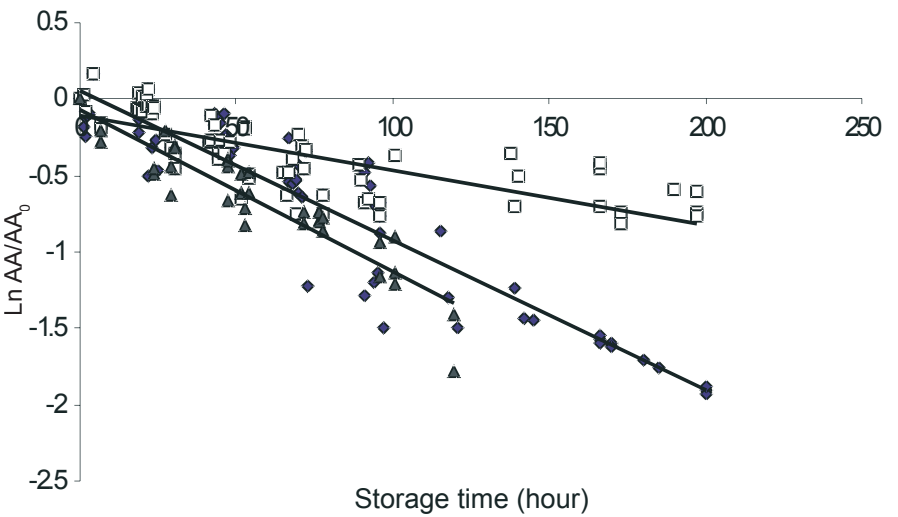

Fig. 2. Ascorbic acid degradation ( $\ln \mathrm{AA} / \mathrm{AA})$ in lettuce leaves stored at $0^{\circ} \mathrm{C}(\diamond)(\mathrm{y}=-0.0036 \mathrm{x}-0.1084, \mathrm{R}=0.76, \mathrm{~N}=70), 8^{\circ} \mathrm{C}(\square)(\mathrm{y}=-0.0098 \mathrm{x}$ $+0.0538, \mathrm{R}=0.93, \mathrm{~N}=56)$ and $15^{\circ} \mathrm{C}(\boldsymbol{\Delta})(\mathrm{y}=-0.0106 \mathrm{x}-0.065, \mathrm{R}=0.92$, $\mathrm{N}=32$ ). AA is the ascorbic acid content (mg AA/100 g sample) at any time of storage and $\mathrm{AA}_{0}\left(\mathrm{mg} \mathrm{AA}_{0} / 100 \mathrm{~g}\right.$ sample) at time zero. Ascorbic acid determination was performed on three different experimental runs at each storage temperature. For each experimental run two samples were taken and analysis were performed in triplicate.

but were significantly different $(P<0.01)$ from the slope of the tendency line for samples stored at $0^{\circ} \mathrm{C}$. These results indicate that ascorbic acid degradation rate in lettuce leaves stored at abusive temperatures was from 2.7 to 2.9 times faster than at $0^{\circ} \mathrm{C}$. After $200 \mathrm{~h}$ of storage at $0^{\circ} \mathrm{C}$ ascorbic acid retention in lettuce leaves was about $46 \mathrm{~g} / 100 \mathrm{~g}$. In samples kept at $8^{\circ} \mathrm{C}$, the retention was about $14 \mathrm{~g} / 100 \mathrm{~g}$. Samples held at $15^{\circ} \mathrm{C}$ were only kept for 100 $\mathrm{h}$, a time at which they were completely spoiled. At that time, the ascorbic acid retention was already down to $22 \mathrm{~g} / 100 \mathrm{~g}$. Tulio et al. (2002) analyzing the effects of storage temperature on the postharvest quality of jute leaves reported that the ascorbic acid content declined in all storage temperature conditions as storage period was increased. However, the reduction in the ascorbic acid contents was gradual at low storage temperatures but rapid at high storage temperatures.

Leafy vegetables lose ascorbic acid in postharvest operations and it has been attributed to both temperature and water loss (Kader, 1999). Changes in water contents in the samples kept in polyethylene bags were minimal and would not suffice to explain the losses in ascorbic acid. Ascorbic acid losses could be attributed to temperature effects and tissue structural changes due to biological deterioration factors (senescence and microbial activity).

Microbial growth: Initial total microbial counts were in the range of 4.0 to $4.4 \times 10^{6} \mathrm{CFU} / \mathrm{g}$. Similar results had been found in a previous work (Roura et al., 2003).

Total microbial counts on lettuce leaves during storage are presented in Fig. 3 as log CFU/g versus time. Experimental results are widely scattered. This may be because determinations were done on three different experimental runs on samples of an actual foodstuff, with the concurring variability associated to biological material.

The growth curve of total microbial counts fitted with the Gompertz and Logistic models including the $\mathrm{r}^{2}$ values are shown in Fig. 3. Parameter A in both models was fixed at the log of the mean initial counts on lettuce leaves $(6.82 \mathrm{CFU} / \mathrm{g})$. Both models produced very similar patterns for total microorganisms growth in samples stored at $0^{\circ} \mathrm{C}$ (Fig. 3A), with an incubation 

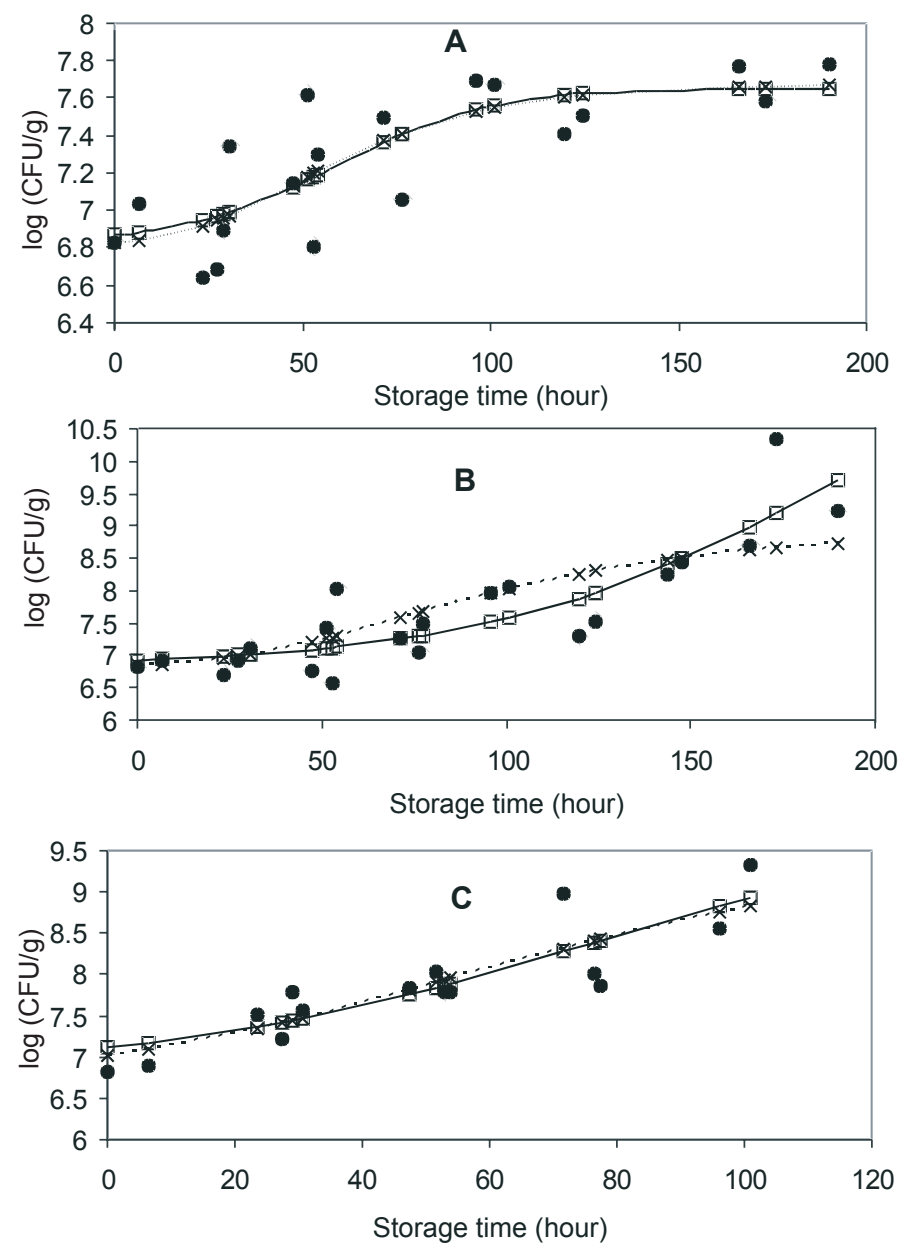

Fig. 3. Growth curve of total microbial during storage at $0^{\circ} \mathrm{C}(\mathbf{A}), 8^{\circ} \mathrm{C}$ (B) and $15^{\circ} \mathrm{C}(\mathbf{C})$ fitted with the Gompertz (--X--, R=0.87) and Logistic models $(\square, \mathrm{R}=0.85)$.

phase lasting about 20-25 h, a logarithmic growth phase and a stabilization phase with logarithmic of microbial populations around $7.65 \mathrm{CFU} / \mathrm{g}$. For samples stored at $8^{\circ} \mathrm{C}$, however, the best fit for the logistic model indicates that the growth of total bacteria is still in the exponential phase after $200 \mathrm{~h}$ of storage (Fig. 3B). On the other hand, the best fit for the Gompertz model, indicates that the stabilization phase would have been reached by $175 \mathrm{~h}$ of storage. The logarithm of microbial populations reached at $8^{\circ} \mathrm{C}$ was around $8.7 \mathrm{CFU} / \mathrm{g}$, that is, about one log cycle above the stabilization value for samples stored at $0^{\circ} \mathrm{C}$. Finally, for samples stored at $15^{\circ} \mathrm{C}$, best fits for both models indicated that the total microbial growth was in the exponential phase after $100 \mathrm{~h}$ of storage (Fig. 3C). It should be pointed out that samples were stored at $15^{\circ} \mathrm{C}$ for only $100 \mathrm{~h}$ because, by that time, they had deteriorated beyond any commercial value.

French regulations imposed $8^{\circ} \mathrm{C}$ as a maximum storage temperature for minimally processed vegetables. This limit was lowered to $4^{\circ} \mathrm{C}$, but vegetables are often stored or distributed at higher temperatures. This legislation allows a maximum of 5.0 $\mathrm{x} 10^{7} \mathrm{CFU} / \mathrm{g}$ for the safe consumption of minimally processed vegetables (Francis et al., 1999). Accepting this value as a threshold that must not be surpassed, from a bacteriological point of view, the keeping time of fresh lettuce would be around 8 days for lettuce kept at $0^{\circ} \mathrm{C} ; 5$ days for lettuce kept at $8^{\circ} \mathrm{C}$ and 2 days for lettuce kept at $15^{\circ} \mathrm{C}$.

The main aspects of this study were the establishment of vitamin
C losses and microbial counts for Romaine lettuce leaves kept at two abusive temperatures and the comparative estimation of their shelf life with respect to the ideal storage temperature $\left(0^{\circ} \mathrm{C}\right)$. For ascorbic acid degradation and microbial evaluation, the profiles obtained were supported through a high number of experimental data (a mean of 52 data per fitted curve) during 100-200 hours after harvest, in order to be able to predict the quality parameters in a reliable way.

Exposure to undesirable temperatures resulted in faster ascorbic acid degradation rates detrimental to nutritional quality. The rate of degradation of ascorbic acid in lettuce leaves stored at abusive temperatures would be from 2.7 to 2.9 times faster than at $0^{\circ} \mathrm{C}$.

If fruits or vegetables are handled at abusive temperatures, sanitizer agents applied to reduce initial microbial counts will do little to extend shelf life or limit microorganism growth. Mishandling of these products, exposing them to abusive temperatures, would make microbial levels go right back up to pre-wash levels or higher. In the present work, only tap water immersion was used to eliminate superficial microflora; in this way, only temperature effects on microbial counts were evaluated.

Model can be a powerful tool for microbial analysis, quickly providing an initial estimate of a microorganism's behavior. In this work, two primary models (Gompertz and Logistic), were compared for their ability to describe the total microbial counts as a function of storage temperatures applied to lettuce. These models allowed us to predict the vegetable microbiological shelf life. Temperature is the controlling factor for lettuce shelf life and quality; microbial quality was retained 1.6 and 4 times longer at $0^{\circ} \mathrm{C}$ with respect to 8 and $15^{\circ} \mathrm{C}$, respectively.

\section{Acknowledgments}

This work was supported by Consejo Nacional de Investigaciones Científicas y Técnicas (CONICET) and Universidad Nacional de Mar del Plata (UNMDP).

\section{References}

Bastrash, S., J. Makhlouf, F. Castaigne and C. Willemot, 1993. Optimal controlled atmosphere conditions for storage of broccoli florets. $J$. Food Sci., 58: 338-341, 360.

Brackett, R.E. 1999. Incidence, contributing factors, and control of bacterial pathogens in produce. Postharvest Biol. Technol., 15: 305-311.

Francis, G. A., C. Thomas and D. O'Beirne, 1999. The microbiological safety of minimally processed vegetables. Int. J. Food Sci. Technol., 34: $1-22$.

Giannakourou, M.C. and P.S. Taoukis, 2003. Kinetics modeling of Vitamin $\mathrm{C}$ loss in frozen green vegetables under variable storage conditions. Food Chem., 83(1): 33-41.

ICMSF, 1983. Métodos recomendados para el análisis microbiológicos en alimentos. In: Microorganismos de los alimentos I. Técnicas de análisis microbiológicos. Acribia S.A., Zaragoza, España, 2da. Ed.

Kader, A.A. 1999. Postharvest technology of horticultural crops. Division of Agriculture and Natural Resource. University of California, Davis, C.A.

Kim, D.M., N.L. Smith and C.Y.C. Lee, 1993. Quality of minimally processed apple slices from selected cultivars. J. Food Sci., 58: $1115-1117$. 
Lee, S. and A. Kader, 2000. Preharvest and postharvest factors influencing vitamin $\mathrm{C}$ content of horticultural crops. Postharvest Biol. Technol., 20: 207-220.

Moreira, M.R., S. Roura, and C. del Valle, 2003. Quality of Swiss chard produced by conventional and organic methods. Lebens.-Wiss. Technol., 36: 135-141.

Moreira, M., A. Ponce, C. del Valle and S. Roura, 2005. Inhibitory parameters of essential oils to reduce a foodborne pathogen. Lebens.Wiss.Technol., 38(5): 565-570.

Mossel, D. A. and B. Moreno García, 1985. Microbiología de alimentos. Acribia S.A. Zaragoza. España. $2^{\text {nd }}$ Edn.

Paull, R.E. 1999. Effects of temperature and relative humidity on fresh commodity quality. Postharvest Biol. Technol., 15: 263-277.

Perrin, P.W. and M.M. Gaye, 1986. Effect of simulated retail display and overnight storage treatment on quality maintenance in fresh broccoli. J. Food Sci., 51: 146-149.

Ricker, W.E. 1979. Growth rates and models. Fish Physiol., 8: 677743.

Roura, S.I., M. del R. Moreira, A. Ponce and del Valle, 2003. Dip treatments for fresh romaine lettuce. Ital. J. Food Sci., 3(15): 405415 .
Sastry, S.K. and D.E. Buffington, 1982. Transpiration rates of stored perishable commodities: a mathematical model and experiments on tomatoes. ASHARAE Transactions, 88(1): 159-184.

Schlimme, D.V. 1995. Marketing lightly processed fruits and vegetables. HortSci., 30(1): 15-17.

Tulio Artemio Z., O.S.E. Kimiko, Chachin Kazuo and Ueda Yoshinori, 2002. Effects of storage temperatures on the postharvest quality of jute leaves (Corchorus olitorius L.). Postharvest Biol. Technol., 26(3): 329-338.

Volk, W. 1980. Applied Statistics for Engineers, Correlation-Regression. Mc Graw-Hill, Inc. New York, $1^{\text {st }}$ Edn.

Watada, A.E., N.P. Ko and D. A. Minott, 1996. Factors affecting quality of fresh cut horticultural products. Postharvest Biol. Technol., 9: 115-125.

Wiley, C.R. 1997. Frutas y hortalizas mínimamente procesadas y refrigeradas. En: Mossel, D. A and Moreno García, B. Microbiología de alimentos. Acribia S.A. Zaragoza. España, $1^{\text {st }}$ Edn.

Zagory, D. 1999. Effects of post-processing handling and packaging on microbial populations. Postharvest Biol. Technol., 15: 313-321.

Zwietering, M., I. Jongenburger, F. Rombouts and K. Van't Riet, 1990 Modeling of the bacterial growth curve. Appl. Environ. Microbiol., 56(6): 1875-1881. 